\title{
Multimodal digital tools and EFL audio-visual comprehension: Student's attitudes towards vodcasts
}

\author{
Natalia Norte Fernández-Pacheco \\ natalynorth@gmail.com \\ CESA Alicante, Spain
}

\begin{abstract}
The emergence of Information and Communication Technologies (ICT) has helped in the development and application of new language teaching materials that promote a multimodal approach (Jewitt, 2009, 2013; Kress and Leeuwen, 2001). Multimodal digital tools, such as vodcasts, bring together diverse modes of communication, which may enhance students' foreign language audio-visual comprehension. This paper discusses a study on the attitudes of 40 Spanish students at a B2 level, aged between 14 and 19 , towards the use of vodcasts, in comparison with audio tracks. Questionnaires were employed to gather data on student attitudes towards two British Council vodcasts. The results showed positive attitudes towards the use of multimodal digital tools (e.g., vodcasts) rather than traditional listening activities (e.g., audio tracks). We suggest these findings point to the potential of vodcasts not only as influential multimodal tools to improve EFL students' audio-visual comprehension but also to increase students' enjoyment and engagement when learning English as a foreign language.
\end{abstract}

Keywords: Multimodality, digital tools, audio-visual comprehension, EFL, students' attitudes, vodcasts

\section{INTRODUCTION}

Though multimodal communication has always existed, there has been a preference for exploring one mode, spoken or written, in isolation. In the $20^{\text {th }}$ century, visuals (e.g., photographs, figures and graphics) started to gain importance in educational contexts and they were included in textbooks to help students in the process of meaning-making and comprehension. Recently, the rapid dissemination of technology has contributed to the expansion and employment of innovative language teaching resources, leading to a shift from printed elements of communication to digital resources (Jewitt, Bezemer, Jones, \& Kress, 2009). These digital tools (e.g., webpages, blogs, social networks, online dictionaries, and vodcasts) support a multimodal approach, due to the range of modes that are employed in their production. From a multimodal perspective, information is transmitted and received from the orchestration of different communicative modes of representation. On the one hand speakers make use of verbal (i.e., spoken and written) and non-verbal modes (i.e., images, music, and body 
movements) to convey meaningful communicative acts. On the other hand, the audience perceive the information from the auditory and visual channels, and activate their cognitive processes to enable audio-visual comprehension. However, audio-visual comprehension does not only take place in interactional or two-way exchanges, but also while using transactional (i.e., one-way) multimodal digital tools such as vodcasts. The use of visuals to enhance foreign language comprehension has acquired a special role during the last decade. Nevertheless, little research has been carried out to check the effects of orchestrating visual and aural inputs to understand foreign language (e.g., Coniam, 2001; Ramírez \& Alonso, 2007; Sueyoshi \& Hardison, 2005; Suvorov, 2009; Wagner, 2007, 2010). This article focuses on students' attitudes towards the use of multimodal digital tools such as vodcasts to improve their EFL audio-visual comprehension. For this purpose, firstly, I provide a review of the most relevant resources and studies related to i) multimodality, ii) the application of multimodal digital resources in language learning settings, and iii) audio-visual comprehension. Secondly, I present a small-scale study ${ }^{1}$ carried out to explore students' viewpoints on audio-visual tools as foreign language listening activities (Norte, 2016). This study paid attention to the EFL students' attitudes towards the use of multimodal digital tools (e.g., vodcasts) in comparison with traditional listening tools (e.g., audio tracks).

\section{THE MULTIMODAL LANDSCAPE}

The diversity of semiotic resources and social contexts involved in communication have produced a great variety of theoretical and disciplinary practices associated with multimodality (O'Halloran \& Smith, 2011). Multimodality, defined as, “...the use of several semiotic modes in the design of a semiotic product or event, together with the particular way in which these modes are combined..." (Kress \& Leeuwen, 2001:20), facilitates the possibilities of identifying, examining and reaching conclusions about the production of meaning though the orchestration of modes in diverse contexts. According to Jewitt (2013), three different premises underlie the multimodal approach. Firstly, language is a part of a multimodal ensemble. That is to say, representation and communication is produced due to the variety of modes that contribute, equally, in the

\footnotetext{
${ }^{1}$ This paper relates to a part of the doctoral thesis presented by the author.
} 
process of meaning. Therefore, multimodality emphasises the idea of analysing all modes produced in multimodal ensembles (representations of more than one mode). Secondly, each mode in a multimodal ensemble is understood as realizing different communicative work. This assumption is based on the way modes have been created from the influence of culture, society and the use throughout history. Consequently, modes could differ from culture to culture and they are shaped by different meaning potentials and semiotic resources. Thirdly, people orchestrate meaning through their selection and configuration of modes. The postulation of this premise draws attention to the technological improvements produced in recent decades with the integration of the internet and new forms of online communication and representation. Due to these improvements, a special interest has grown about how modes work, semiotically speaking, and how they are used in online discourse.

The interest in multimodality in recent times has arisen from the arrival and the rapid spread of technology. New technologies (multimedia and mobile technologies) have taken a more prominent position in our lives and created new ways of representing and communicating meaning. Since the development of the internet in the 1990s and other technological tools, a generation of "digital natives" (Prensky, 2001:1) has arisen. Digital natives are very much familiar with the use of laptops, smartphones, video cameras, digital music and video players, videogames and many other electronic gadgets. This acquaintance with technology, or digital literacy, seems to be innate among 'natives' and its acquisition has been compared to that of their mother tongue. In contrast, those who were born before this technological impact, known as "digital immigrants" (Prensky, 2001:1), have felt the pressure of having to adapt to this new technological situation. One of the main reasons for this necessity to adjust to technological improvements is due to the emergence of new forms of communicative discourses found in social media and social networks. These discourses (e.g., Facebook, Twitter, YouTube, and WhatsApp) are distinguished by their potentials in the multimodal landscape, due to the great variety of modes that are employed in their designs. Although it was believed that previous discourses, without technology, did not include more than one mode, there was a tendency of orchestrating written language and images (Bezemer \& Kress, 2014b). In the $21^{\text {st }}$ century, coined as the era of digitalization, people, especially youth, are more aware of the technological affordances 
of different semiotic resources (e.g., moving images, still images, typography, sounds and colours). As a consequence, more and more multimodal texts are appearing, making an effort to facilitate comprehension. Due to this growth in the assembly of multimodal texts, new theoretical means are necessary to have a better understanding of how they operate in the process of meaning making (Ventola, Charles, \& Kaltenbacher, 2004:1).

The various possibilities of combining communication modes in the 'new' media, like the computer and the Internet, have forced scholars to think about the particular characteristics of these modes and the way they semiotically function and combine in the modern discourse worlds.

As happened centuries before with written and spoken language, a framework, that explains how these texts are created and how they can be produced, is required. That is to say, there is a need for a kind of meta-language related to other modes apart from language, such as images (still or moving) and gestures, among other modes of representation, that will help in the designing and production of multimodal texts (Bezemer \& Kress, 2014a).

\section{MULTIMODAL DIGITAL LANGUAGE LEARNING RESOURCES: VODCASTS}

The development of vodcasts (i.e., video recordings uploaded onto the net with RSS feeds), during the last number years has been possible due to the widespread use of the Internet around the world, the creation of broadband technologies which permit users to download large media files, the familiar use of multimedia personal computers, the opportunity of streaming and downloading as separate actions, and the ubiquity of new technological devices (Campbell, 2005). Moreover, the advances in software (e.g., Audacity and Odeo) to create vodcasts and podcatchers (e.g., podOmatic, Education Podcasts, iTunes) to upload and download them have contributed to their proliferation. Vodcasts are characterised by their use in different settings, for this reason, they have been categorised (Evans, 2008) as a form of mobile learning (m-learning), which allow students "learning across multiple contexts, through social and content interactions, using personal electronic devices" (Crompton, 2013:4). In language learning contexts, vodcasts may be considered quite beneficial for students. Some of these possible benefits are included in Table 1. On the internet, we can find vodcasts related to a wide range of themes such as politics, the news, radio, television, music, fashion and beauty, 
literature, arts and entertainment, comedy, education, health, games and hobbies, and technology, among others. This diversity of topics allows language teachers and students to choose those vodcasts that are more suitable to their interests.

Table 1. Benefits of using language learning vodcasts

\section{Benefits}

Foster an active role of the learner.

Promote flexible learning, anytime and anywhere.

Foment participation and collaborative-peer activities.

Facilitate the introduction of different communicative modes.

Adjust to students' learning styles, difficulties and disabilities.

Offer a great variety of topics creating rewarding learning experiences.

Distribute authentic-content situations.

Support formal and informal learning.

Promote blended learning environments.

The application of multimodal digital learning resources, such as vodcasts in traditional language learning environments is becoming quite common not only because of technological advances, but also by the interest in facilitating language learning. This new form of educational situation is known as blended language learning (henceforth, BLL). BLL is defined by Stracke (2007: 57) as "a particular learning and teaching environment, that combines face-to-face (f2f) and computer assisted language learning (CALL)". Thus, as represented in Figure 1, blended language learning embraces the use of traditional language lessons, in which there are teacher-students and studentsstudents interactions, and the use of technology-mediated language learning activities to contribute in the process of language learning. 


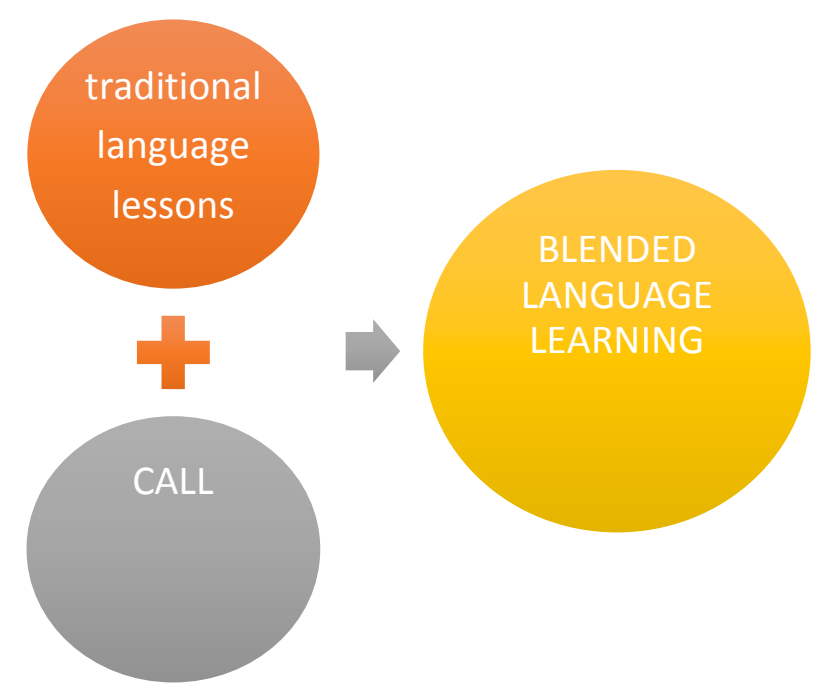

Figure 1. Components in blended language learning.

Traditional face-to-face language instruction is related to language learning situations in which teachers and students interact inside the classroom without the use of technologies. This kind of language instruction has been predominant during centuries and research has been carried out to identify significant issues with regard to these interactions (e.g., negotiation of meaning and the influence of interactive and noninteractive lectures), and how they could be influential on students' language learning (e.g., Allwright, 1984; Cazden, 1988; Chaudron, 1988; Morell, 2000, 2004; Sinclair \& Coulthard, 1975).

CALL makes use of technological devices to facilitate the learning process without the need to have both, teacher and learners, together in the same setting. This form of instruction also takes into account a variety of modes to present information, even in a more powerful way than in traditional lessons. The orchestrations of modes produced by technological devices are more engaging for teachers and students, and consequently, they may influence the language learning process in some way.

When combining these two leading forms of multimodal representation (i.e., traditional lesson and technology-mediated instruction) the process of language learning takes a new perspective in which multimodal communication gains great importance. Recently, several scholars (e.g., Chinnery, 2006; Kukulska-Hulme, 2013) have proposed a new form of CALL in which mobile technologies are used for language learning purposes, i.e. mobile-assisted language learning (MALL). MALL is described as "mobile 
technologies in language learning, especially in situations where device portability offers specific advantages" (Kukulska-Hulme, 2013: 3701). The field of MALL is not considered independent but related to CALL and mobile learning (i.e., learning everywhere and anytime using electronic devices), apart from second language acquisition (Stockwell \& Hubbard, 2013). MALL differs from CALL in "its use of personal, portable devices that enable new ways of learning, emphasizing continuity or spontaneity of access and interaction across different contexts of use" (Kukulska-Hulme \& Shield, 2008: 273). In other words, MALL promotes the use of mobile tools and mobile learning.

Little research has been done on vodcasts to better understand their efficacy on students' comprehension, and particularly, improving foreign language audio-visual comprehension. Basically, research on listening skills in language learning courses has been performed through the analysis of audio podcasts. Moreover, much attention has been given to students' attitudes and perceptions towards the use of audio podcasts rather than the effects podcasts could produce on learning outcomes. Results about the students' perceptions towards the use of podcasts have been quite positive (Kavaliauskiene \& Anusiene, 2009; Chan, Chi, Chin, \& Lin. 2011; O’Bryan \& Hegelheimer, 2007). However, the experiences can differ among students and teachers according to their knowledge on the use of technologies (Kim \& King, 2011). In different reports students have also shown their worries about the length and style of podcasts (Li, 2012; Chan, Lee, \& McLoughlin, 2006). In the landscape of foreign language listening comprehension, Ashraf, Noroozi and Salami (2011) performed a study to check the effects of promoting listening skills in EFL situations through the use of audio podcasts. They proved that students in the experimental group (listening to audio podcasts) obtained better listening results than the ones in the control group (listening to English radio programs). Students stated their preferences towards audio podcasts for several reasons: the ease of access, the possibility of listening to them at any time and place, low- speed speech and the opportunity of listening to podcasts several times. Abdu and Abdul (2012) carried out an experimental study in Yemen with 60 students. It aimed to analyse the effects of audio podcasts and vodcasts as supplementary material in traditional English language listening courses. Through listening tests and the compilation of students' attitudes, they produce some evidence 
supporting the use of podcasts and vodcasts compared to traditional listening courses. Abdous, Camarena, and Facer (2009), in their study comparing integrated and supplementary podcasts in foreign language courses, reaching the conclusion that students who used audio and video podcasts had positive perceptions towards them. Furthermore, students found podcasts quite useful in reference to their use as learning tools to improve their language skills (listening, speaking and vocabulary). Campos (2012) focused his research on measuring the effectiveness of listening to vodcasts to improve listening skills in foreign language learning. The results obtained through his experimental study concluded that vodcasts were a great pedagogical resource, especially due to the fact that, when $71.8 \%$ of the subjects stated real improvement on speaking and listening skills; $81 \%$ of the subjects believed they could learn pronunciation better, and $93.7 \%$ of the subjects manifested the effectiveness as an English learning tool according to the participants.

\section{EFL AUDIO-VISUAL COMPREHENSION}

Up until the 1990s not much attention was given to the instruction and assessment of foreign language listening (Rost, 2002). However, in the last 25 years, research related to the Cinderella skill (as named by Mendelsohn, 1994), as listening was considered, has increased and evolved into new approaches. Although listening is defined as the action of "processing information which listeners get from visual and auditory clues in order to define what is going on and what the speakers are trying to express" (Rubin, 1995:151), studies on this language skill and its strategies have been mainly focused on auditory input. Little attention has been given to describe the influence of non-verbal cues in the construction of meaning and comprehension using audio-visual resources. Due to technological advances and the proliferation of audio-visual materials in language learning contexts, new research directions have arisen to describe the different effects of auditory, audio-visual or multimedia inputs on students' comprehension. When referring to the process of audio-visual comprehension, it is not only necessary to describe the information processing model (Anderson, 2009) and its phases (i.e., perception, parsing and utilization), but also the language learning strategies and listening strategies (i.e., metacognitive, cognitive and socio-affective strategies) that are recommended by researchers of the field (Bacon, 1992; Goh, 2002; Goh \& Taib, 2006; 
Lynch, 2009; Mendelsohn, 1994; O’Malley \& Chamot, 1990; Rubin, 1994; Vandergrift, 1997, 2003; Vandergrift et al., 2006).

As mentioned previously, audio visual resources, such as vodcasts, are associated to the concept of multimedia, which refers to the combination of multiple forms of media (i.e., text, sounds, images, graphics and animations) in a digital system. Therefore, the use of vodcasts, as multimodal and multimedia tools, and students' audio-visual comprehension might be associated with the Cognitive Theory of Multimedia Learning (CTML) by Mayer $(2005,2009)$. This theory is based on the dual-channel assumption, taken from Clark and Paivio's (1991) dual-coding theory, which emphasises that "the human information-processing system contains an auditory/verbal channel and a visual/pictorial channel" (Mayer, 2005: 33).Thus, one of the main reasons leading towards CTML is its concern with auditory and visual modalities for comprehension and learning. That is to say, comprehension increases when information is perceived from different channels. Consequently, audio-only materials may not be as effective as multimodal material.

The use of visuals to enhance foreign language comprehension has acquired a special role during the last decade. However, little research has been carried out to investigate the effects of orchestrating visual and aural inputs to understand foreign language. Some scholars (e.g., Sueyoshi \& Hardison, 2005; Ramírez \& Alonso, 2007; Wagner, 2010) lean towards the positive effects of video resources since they display relevant elements (i.e., non-linguistic knowledge) necessary to facilitate comprehension. Other studies (e.g., Coniam, 2001; Suvorov, 2009), which compared audio and visual modes in listening tests were inconclusive. Among the studies that have determined that visuals help students to better perform listening tests, Ramírez and Alonso (2007) prepared a quasi-experimental research study to check the effects of digital stories (in English) on six-year-old Spanish students and claimed positive results from the experimental (watching digital stories) over the control group. Digital stories allowed children to comprehend linguistic structures and vocabulary. Moreover, students were able to give some feedback despite their lower proficiency level of English. Another idea emphasized by Ramírez and Alonso is the level of attention students had while watching digital stories. They concluded in favour of using internet-based technologies with songs, games, and stories, since they may contribute in the process of 
comprehension. Wagner (2010), compared two groups of students on an ESL listening test. The control group took the listening test with audio input while the experimental group carried out the same listening test through video input. The results demonstrated that non-verbal information from the video positively influenced students' performance. Sueyoshi and Hardison (2005) focused their attention on the role of speakers' faces and gestures from videotexts and how they contributed to second language learners' listening comprehension. Forty-two low-intermediate and advanced learners of English, were distributed according to three different stimulus: audio-visual including gestures and face expressions, audio-visual with no gestures, and audio-only. From the comprehension tasks, Sueyoski and Hardison determined that students from both levels of English performed better when visual cues were shown. However, higher-level students obtained better results in the audio-visual condition including face, and lowerlevel students when the input was audio-visual including gestures and face. Data from questionnaires reported students' positive attitudes toward visual cues, especially in face-to-face interactions.

As we have reviewed in the previous sections, research on podcasts and language learning has mostly been concerned with audio podcasts and students' attitudes, but scarce research has focused on connecting multimodality, vodcasts and audio-visual comprehension. For this reason, based on the multimodal approach of meaning making ( Jewitt, 2009; Kress \& Leeuwen, 2001) and taking into account the importance of dual-channels in the CTML (Mayer, 2005, 2009), this study pays attention to EFL students' perceptions towards vodcasts in comparison to audio listening activities

\section{METHODOLOGY}

This small-scale study attempts to answer the following research questions, "What are the students' attitudes towards the use of audio-visual (e.g., vodcasts) compared to traditional audio (e.g., audio tracks) comprehension activities in language learning contexts?" and "Do students believe that multimodal digital tools (e.g., vodcasts) could help them to improve their level of English?” Taking into consideration these research questions, we have designed the following study which attempts to begin to fill the gap of multimodal digital tools (e.g., vodcasts) and audio-visual comprehension. 


\section{1. The participants}

The participants of this study were 40 Spanish students, 15 males and 25 females, aged between 14 and 19, from a private language school in Alicante. They were enrolled in an Upper-intermediate or B2 level course, according to the Common European Framework of Reference for Languages (CEFR). These students had been learning English as a foreign language for approximately 8 to 10 years, and they had passed the Intermediate level or B1 level in this language school. Students had been accustomed to using audio tracks for listening comprehension activities, and to following the same ritualised procedure. First, they would read the questions, then, they would listen twice to the recording, and finally, they would answer the questions while listening. Once the students had completed the exercise, their teacher would give feedback on the answers, referring to unknown vocabulary, idiomatic expressions, pronunciation, etc. Although their textbooks included audio-visual resources (e.g., video extract with authentic realworld interviews, MultiROMs, iPack, online resources), the participants of this study were accustomed to carrying out audio comprehension activities without visuals. The main reason for not implementing audio-visual resources on a regular basis was due to a lack of technological infrastructure at the school.

\section{V.2. The vodcasts}

The two vodcasts employed in the study are called English is GREAT, part 1 and Camden Fashion. They are taken from iTunesU and they are free downloads. English is GREAT (part 1) belongs to the series of vodcasts Britain is GREAT. The first vodcast has a duration of 5 minutes and 18 seconds and explains how the English language has evolved over the years. Richard, the presenter, goes to the British library in London to interview Roger Walshe, the Head of Learning. The vodcast informs viewers of the items in the library, the impact of the Industrial Revolution, the influence of the Internet on English, and the versatility of the language. The second vodcast, Camden Fashion, is part of the series of vodcasts Word on the Street has a duration of 4 minutes and 28 seconds. One of its notable characteristics is the presence of written prompts on the screen. In Camden Fashion, Carmen, the presenter, goes to Camden market to explain the variety of fashion styles that can be found there. First, she talks about the history of the market and the importance it has had for punk fashion. She also describes the main 
characteristics attributed to punks over time. Other fashion styles, such as British fashion and Cyber-Goth are also mentioned throughout the vodcast. In addition, Angela, from the Grazia daily, gives details about British fashion and the London Fashion Week. Finally, Carmen interviews Jack, who defines Cyber-Goth style.

The reason for choosing vodcasts from the British Council was two-fold: first, because of the notable reputation of this organization in language education. Second, because of the connection of the vodcasts to the specific syllabus of the participants of the study. Moreover, they fulfil some of the characteristics (i.e., exposure to the language, authenticity and length) established by Rosell-Aguilar (2007) to bear in mind when choosing vodcasts for language learning purposes. And finally, both vodcasts contained a variety of semiotic modes of communication (i.e., still images, gestures, written language, spoken language and music) which helped in the construction of meaning making.

\section{V.3. The questionnaire}

After the viewing of these two vodcasts, which were used as add-on activities, as described by Rosell-Aguilar (2007: 476) and Hew (2009: 337), students filled in a questionnaire (see appendix A) about their attitudes towards listening to audio tracks and watching vodcasts. In the questionnaire, students provided information about their level of English, age, sex, nationality, and the years studying English. This information was relevant to collect data related the characteristics of each participant. Then, they answered 6 likert-scale questions $(1=$ strongly disagree to $5=$ strongly agree), related to audio listening activities and vodcasts. These statements were focused on aspects such as sound quality, length, speed, entertainment, understanding and anxiety. The selection of these parameters are grounded on some complaints that students manifested throughout the course while doing audio listening activities. Finally, they answered two open questions related to preference and language improvement, Do you prefer doing activities with video podcasts or the usual listening activities? Why? and Do you think that the use of video podcasts could help you to improve your level of English? Why?

\section{RESULTS}

On the first question, which asked students whether they thought the sound quality of 
the vodcasts was better than usual, $92.5 \%$ either agreed or strongly agreed. Responses to question two on the length of the vodcasts, showed that more than two thirds of students $(72.5 \%)$ did not believe they were too long. On the third question, which asked if they considered that the speakers in the vodcasts talked slower than those in the normal audio exercises, many students answered in a neutral way $(23.5 \%)$ or disagreed (27.5\%). Question 4 asked students if they thought that vodcasts were more enjoyable and entertaining than the audio listening activities from the textbook, to which more than half agreed or strongly agreed (82.5\%). On the fifth question, which asked if they deemed vodcasts more difficult to understand than the activities in class, the vast majority disagreed (45\%) or strongly disagreed (27.5\%). Finally, question 6, confirmed that students' anxiety was reduced with the vodcasts since $47.5 \%$ agreed or strongly agreed and $42.5 \%$ showed a neutral attitude. All these results are represented in the following graphs (Figures 2-7).

1. I found vodcasts' sound quality better than in the usual audio activities.

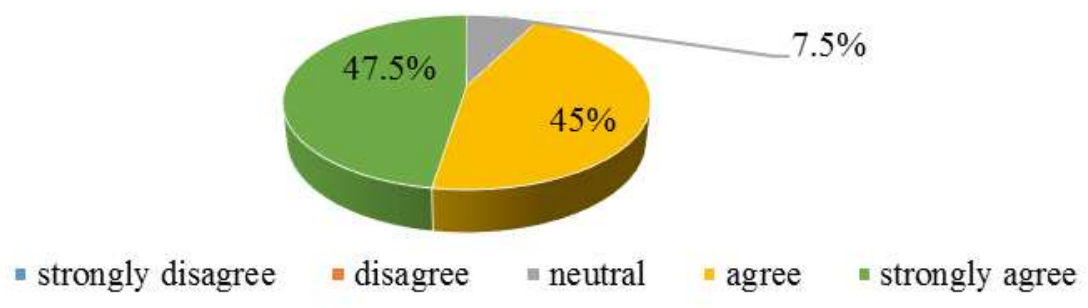

Figure 2. Statement 1: comparing sound quality between vodcasts and audio activities.

2. I found vodcasts too

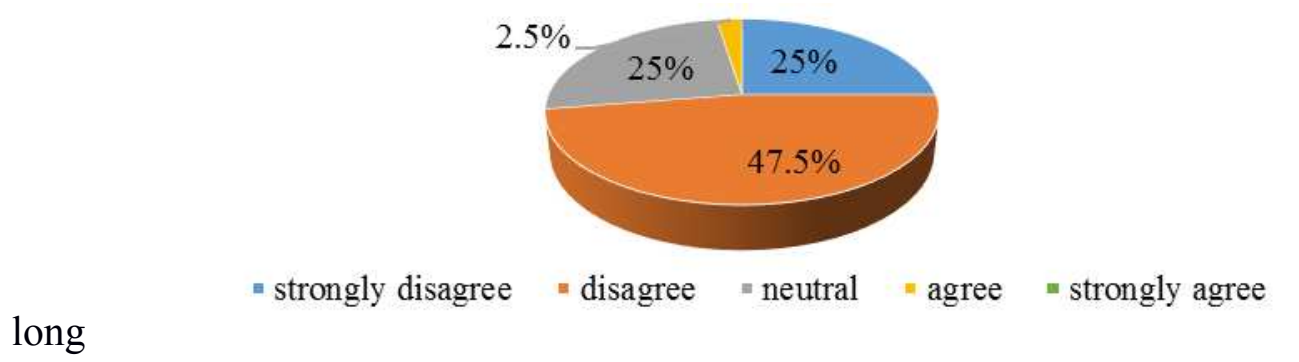

Figure 3. Questionnaire statement 2: students' attitude towards vodcasts length. 
3. I found the speakers in the vodcasts talked slower than the ones we listen to in normal audio exercises.

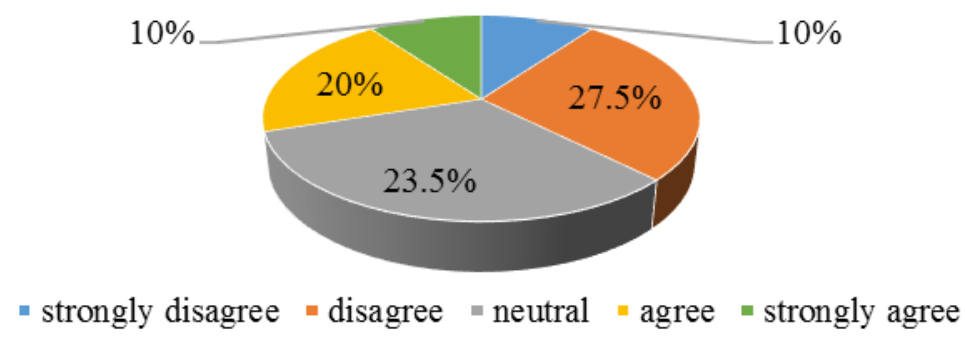

Figure 4. Questionnaire statement 3: students' attitudes towards speakers' speed in audio exercises and vodcasts.

4. I found vodcasts more enjoyable and entertaining than the listening activities from the textbook.

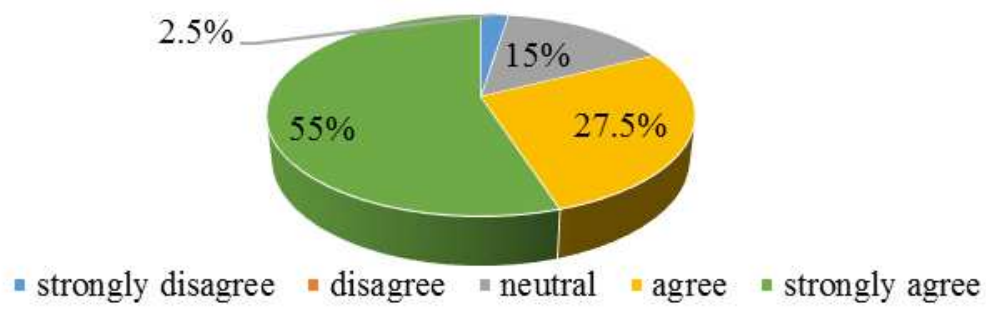

Figure 5. Questionnaire statement 4: students' attitudes towards enjoyment comparing vodcasts and audio listening activities.

5. I found vodcasts more difficult to understand than the activities in class.

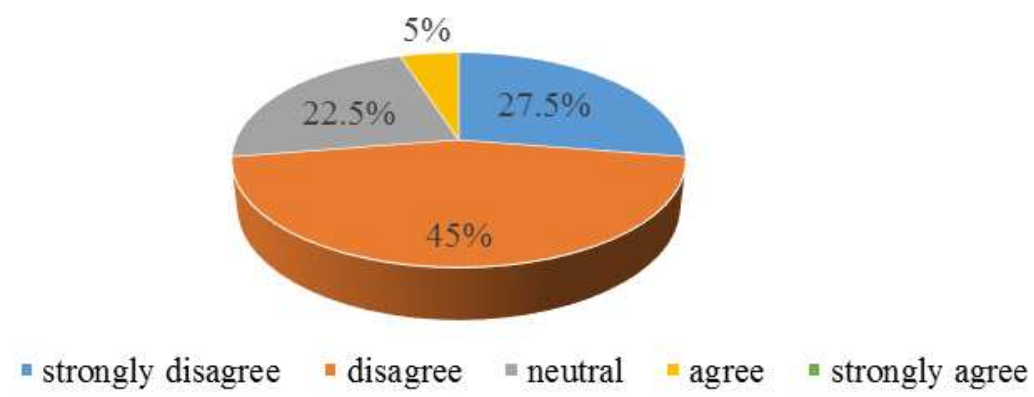

Figure 6. Questionnaire statement 5: students' attitudes towards the difficulty of understanding vodcasts. 
6. I felt less anxious watching vodcasts and answering the exercises than in the usual listening activities.

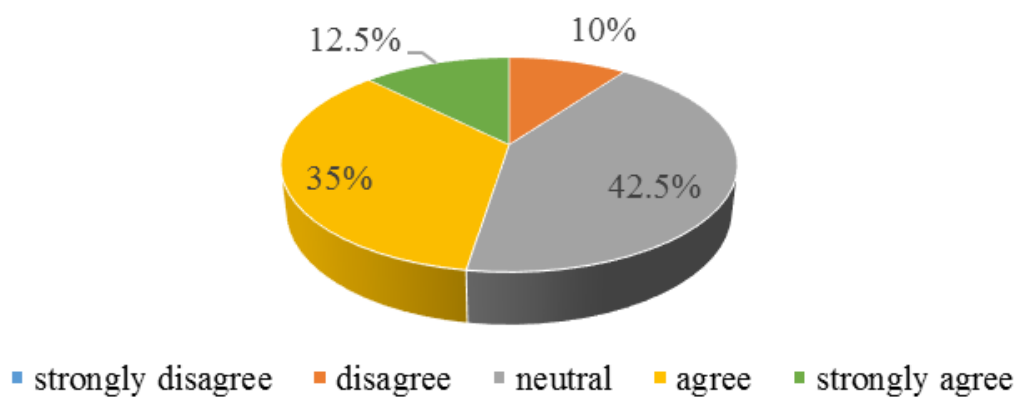

Figure 7. Questionnaire statement 6: students' attitudes towards the anxiety produced by vodcasts and audio listening activities.

At the end of the questionnaire there were two open questions related to preferences and opinions. These questions were included to have a more qualitative point of view since the previous statements just showed information about the students' opinions without making reference to any reason for those ways of thinking. To the question, Do you prefer doing activities with video podcasts or the usual listening activities? $90 \%$ of students seemed to show more positive attitudes towards the use of vodcasts as illustrated on Table 2 .

Table 2. Reasons supporting the use of vodcasts

\section{Reasons supporting the use of vodcasts}

They are more enjoyable/ interesting/ more fun/ exciting.

They are easier /clearer to understand (because you see the people while talking).

I feel more active when I see the video.

I pay more attention/ I am more concentrated.

I can see the people who are talking.

They make you feel good and not nervous.

They are more useful to understand the situation easily. 
The images and movements help you to understand.

The context helps to know what they are talking about.

Speakers speak more slowly.

To the question, Do you think that the use of video podcasts could help you to improve your level of English? $97.5 \%$ of students had a positive attitude towards the use of vodcasts to improve their level of English. The most significant reasons to reinforce their answers are represented in Table 3.

Table 3. Reasons supporting the improvement of language learning using vodcasts

\section{Reasons supporting language improvement using vodcasts}

- You understand them better.

- I focus more on the context.

- They help me to learn vocabulary and expressions.

- They are less boring.

- When you watch videos you learn English - You learn pronunciation.

better.

- You learn more when you see pictures or a - The sound quality is better. film.

-You can interpret better when you see the - I can improve listening and speaking person talking. skills.

- As I enjoy watching the video, I learn - They are quite natural. 
better.

\section{CONCLUSIONS AND DISCUSSION}

This study focused on analysing EFL students' attitudes towards the use of multimodal digital tools (e.g., vodcasts) in comparison with traditional listening tools (e.g., audio tracks). The idea of gathering together students' point of views about new forms of teaching may be considered essential to improve their learning life. In order to determine the students' opinions, they completed a questionnaire based on a range of parameters mentioned previously: sound quality, length, speed, enjoyment, difficulty, anxiety, preference and language improvements. In general terms, and answering our first research question, "What are the students' attitudes towards the use of audio-visual (e.g., vodcasts) compared to traditional audio (e.g., audio tracks) comprehension activities in language learning?", we could say that students preferred audio-visual comprehension activities.

From the questionnaires, we have found that students seem to have a positive attitude towards the use of vodcasts (Abdous et al., 2009; Abdu \& Abdul, 2012). Results from the first question (sound quality) showed that students preferred vodcasts in terms of sound. This outcome may have been influenced by the novelty of new technologies and the devices used to record and watch vodcasts. We must take into account that these language learners were used to doing listening activities (only audio) with a CD player. This technological aspect may have influenced the students' attitudes since the sound quality produced by some radio speakers is not comparable to other kinds of speakers. The results from the second question (i.e., length) were quite significant. Although the audio tracks that these upper-intermediate students were used to listening to were shorter in time (2-3 minutes), the vast majority of students did not have the sense of being watching the vodcasts for a long time, despite they lasted more (4-5 minutes) than the normal audio listening activities. This fact might be connected to the idea of amusement, that is to say, when people are watching or doing something that they really like, they lose all sense of time. Furthermore, the orchestration of different semiotic resources (e.g., spoken and written language, music, kinesics and images) could change students' time perception since they are not just focused on a piece of paper trying to 
understand every spoken single word. The third question, devoted to speed, results were quite diverse. As a consequence, we cannot confirm that speed is a prominent parameter to be considered for students in the preference between vodcasts and audio tracks. It is important to bear in mind that B2 students (Common European Framework of Reference for Languages, CEFR) are exposed to foreign language materials according to their level, and consequently in upper-intermediate, speakers' speech speed should be the same not only in audio tracks, but also in audio-visual materials. Question 4 was included to determine if students enjoyed watching vodcasts in comparison to listening to audio tracks. $82.5 \%$ of students reported that they found vodcasts more enjoyable and entertaining. This could be due to the innovative technological situation in which language learners were involved. Since the students selected for the study are digital natives (Prensky, 2001), they might enjoy more language learning using technological devices (e.g., whiteboards and laptops) rather than printed materials (e.g., books). Furthermore, as was mentioned before, the use of different semiotic resources or multimodal tools, might also contribute to the students' preferences. Currently, the use of visuals, kinesics and musical elements, among others, is deeply-rooted in the era of digitalization and language teachers do not have to forget that students are used to including these resources as part of their construction of meaning-making (Jewitt, 2013). The development of meaning-making is also linked to understanding and comprehension. For this reason, the fifth question was focused on the students' opinions about the difficulty of understanding vodcasts and audio tracks. The results from students exposed that vodcasts were considered easier to understand than audio tracks. These results could be comparable to those from the studies by Sueyoski and Hardison (2005) and Wagner (2010), which showed a notable preference for video materials. We have to consider that vodcasts are multimodal audio-visual materials that combine a range of modes to help in the process of meaning-making. Thus, the combination of verbal and non-verbal modes might be useful to enhance foreign language comprehension. The sixth question, related to anxiety, was included to measure if students felt anxious trying to understand the messages represented in the vodcasts. According to the percentages, more than half of students felt less anxious watching vodcasts and answering the exercises than in usual activities. The level of anxiety could have been reduced due to the pre-reading of the questions from the exercises. In that 
way, they were able to gain previous knowledge about what the vodcasts were about. As the orchestration of modes in audio-visual material help in the construction of meaning-making, the level of difficulty to understand the message might decrease, and consequently, the level of anxiety. The easier the message is to understand, the lower the level of anxiety is. For his reason, it is important that teachers pay more attention to the selection of adequate materials and teaching methods so students could feel more confident and less anxious.

Question 7 gave us important information to suggest the students' positive attitudes towards vodcasts, in terms of preference. Moreover, the answers given were quite considerable to create a link between multimodality and audio-visual comprehension. As reported in Table 2, students preferred watching vodcasts because they were easier to understand due to the context in which the speech was included (i.e., written words, kinesics, music, and images). As stated by some students "the images and movements help you to understand" and "the context helps to know what they are talking about". They expressed the importance of images and gestures to enhance audio-visual comprehension and to catch their attention in favourable learning conditions (i.e., less nervous). From these results, we could imply that the use of several modes influences students' comprehension in language learning contexts. And consequently, they reinforce the relevance of the CTML (Mayer, 2005, 2009) and the use of materials in which students employ dual-channels (verbal/auditory and visual/ pictorial) to better understand information.

Finally, question 8 was used to answer the second research question, "Do students believe that multimodal digital tools (e.g., vodcasts) could help them to improve their level of English?" The high percentage of positive answers confirmed the students' willingness to use multimodal digital tools to improve their foreign language learning. From the reasons given to support this idea, students put special emphasis, once again, on the importance of context, the use of visual and aural channels to understand messages, the natural dialogues, and the possibility to improve other skills (e.g., speaking) apart from listening.

In sum, this particular group of students had overwhelmingly positive attitudes towards the use of multimodal digital tools such as vodcasts. These findings suggest the 
potential efficacy of vodcasts as tools that may increase both student enjoyment and engagement as well as aural/oral learning outcomes in the FL classroom, making use of a variety of communicative modes. Due to the importance to verbal and non-verbal elements to increase comprehension reported by students, further research should be done to measure how the orchestration of verbal and non-verbal modes could be influential on students' audio-visual comprehension. Multimodal discourse analyses (Kress \& Leeuwen, 2001; Norris, 2004, O’Halloran \& Smith, 2011) of multimodal digital materials may help in the identification of the modes orchestrated and the design of audio-visual comprehension activities. This fact could help foreign language teachers to better select the materials they use so as to enhance students' audio-visual comprehension. The development and employment of language teaching materials with suitable orchestrations of modes according to our students' needs, may favour students' language learning experience. Furthermore, other interesting lines of research could be followed, for instance, how vodcasts, as mobile-assisted language learning materials, can influence on language learning (Chinnery, 2006; Kukulska-Hulme, 2013). Nowadays, in the era of digitalization, the use of technologies inside and outside language classrooms should not be something exceptional. Therefore, the idea of blended language learning environments could be expanded in the interests of students. For this reason, it is important that language teachers are aware of the numerous advantages that multimodal digital tools can offer to students in their language learning process. The application of multimodal digital materials (e.g., vodcasts) in language learning contexts may facilitate what students consider a difficult task, learning a foreign language.

\section{REFERENCES}

Abdous, M., Camarena, M. M., and Facer, B. R. 2009. "MALL technology: Use of academic podcasting in the foreign language classroom". Recall, 21 (1), 76-95. doi:10.1017/S095834400900002

Abdu, M. and Abdul, N. 2012. "The application of podcasting and vodcasting in English". Scottish Journal of Arts, Social Sciences and Scientific Studies, 2 (1), 108-117. 
Allwright, R. L. 1984. “The importance of interaction in classroom language learning". Applied Linguistics, 5 (2), 156-171.

Anderson, J. R. 2009. Cognitive psychology and its implications. New York: Worth Publishers.

Ashraf, H., Noroozi, S., and Salami, M. 2011. "E-listening: The promotion of EFL listening skill via educational podcasts". Proceedings of the International Conference on e-Learning, 10-17.

Bacon, S. M. 1992. “The relationship between gender comprehension, processing strategies, and cognitive and affective response in foreign language listening". The Modern Language Journal, 76 (2), 160-178.

Bezemer, J. and Kress, G. 2014a. "Touch: a source for meaning making". Australian Journal of Language and Literacy, 37 (2), 77-85. Retrieved from http://eprints.ncrm.ac.uk/3378/1/Kress_\%26_Bezemer_2014Touch_A_Resource for Making Meaning.pdf

Bezemer, J. and Kress, G. 2014b. "Young people, Facebook and pedagogy: Recognizing contemporary forms of multimodal text making”. In M. Kontopodis, C. Varvantakis, M. Dafermos, and C. Wulf (Eds.) Youth, tube, media: Qualitative insights and international perspectives. Berlin: Waxmann. Retrieved from https://www.academia.edu/6916873/Young_people_Facebook_and_Pedagogy_Re cognizing Contemporary Forms of Multimodal Text Making

Campbell, G. 2005. "There is something in the air: Podcasting in education". EDUCAUSE Review, 40(6), 32-46. Retrieved from http://eric.ed.gov/?id=EJ745798

Campos, A. 2012, November. "Videopodcasts in English language learning: a great tool or another gimmick?" ICERI2012 Proceedings 5th International Conference of Education, Research and Innovation, 5359-5363.

Cazden, C. B. 1988. Classroom discourse: The language of teaching and learning. Portsmouth: Heinemann Educational Books. 
Chan, A., Lee, M. and McLoughlin, C. 2006. "Everyone's learning with podcasting: A Charles Sturt University experience". In Proceedings of the 23rd annual conference: Who's learning? Whose technology? ASCILITE 2006, 111-120.

Chan, W. M., Chi, S. W., Chin, K.N. and Lin, C.Y. 2011. "Students' perceptions of and attitudes towards podcast-based learning". Electronic Journal of Foreign Language Teaching, 8 (1), 312-335. Retrieved from http://e-flt.nus.edu.sg/

Chaudron, C. 1988. Second language classrooms: Research on teaching and learning. Cambridge: Cambridge University Press.

Chinnery, M. G. 2006. "Going to the MALL: Mobile assisted language learning". Language Learning and Technlogy, 10 (1), 9-16.

Clark, J. M. and Paivio, A. 1991. "Dual coding theory and education". Educational Psychology Review, 3 (3), 149-170.

Coniam, D. 2001. "The use of audio or video comprehension as an assessment instrument in the certification of English language teachers: A case study". System, 29, 1-14. doi:10.1016/S0346-251X(00)00057-9

Crompton, H. 2013. "A historical overview of mobile learning: Toward learner-centred education”. In Z. Berge \& L. Muilenburg (Eds.) Handbook of mobile learning. New York: Routledge, 3-14

Evans, C. 2008. "The effectiveness of m-learning in the form of podcast revision lectures in higher education". Computers \& Education, 50, 491-498. doi:10.1016/j.compedu.2007.09.01

Goh, C. 2002. "Exploring listening comprehension tactics and their interaction patterns". System, 30 (2), 185-206. doi:10.1016/S0346-251X(02)00004-0

Goh, C. and Taib, Y. 2006. "Metacognitive instruction in listening for young learners". ELT Journal, 60 (3) doi:10.1093/elt/cc1002

Hew, K. F. 2009. "Use of audio podcast in K-12 and higher education: A review of research topics and methodologies". Education Tech Research, 57, 333-357. doi:10.1007/s11423-008-9108-3 
Jewitt, C. (Ed.) 2009. The Routledge handbook of multimodal analysis. London: Routledge.

Jewitt, C. 2013. "Multimodal methods for researching digital technologies". In S. Price, C. Jewitt, \& B. Brown (Eds.). The SAGE handbook of digital technology research. London: Sage, 250-265.

Jewitt, C., Bezemer, J., Jones, K. and Kress, G. 2009. “Changing English? The impact of technology and policy on a school subject in the 21st century". English Teaching: Practice and Critique, 8 (3), 8-20. Retrieved from http://edlinked.soe.waikato.ac.nz/research/files/etpc/files/2009v8n3art1.pdf

Kavaliauskienė, G. and Anusienė, L. 2009. "English for specific purposes: podcasts for listening skills". Santalka. Filologija. Edukologija, 17 (2), 28-37. doi:10.3846/1822-430X.2009.17.2.28-37

Kim, D. and King, K. P. 2011. "Implementing podcasts and blogs with ESOL teacher candidates' preparation: Interpretations and implications". International Forum of Teaching and Studies, 7 (2), 5-19.

Kress, G. and van Leeuwen, T. 2001. Multimodal discourse: The modes and media of contemporary communication. London: Edward Arnold.

Kukulska-Hulme, A. 2013. "Mobile-assisted language learning”. In C. Chapelle (Ed.), The encyclopedia of applied linguistics. New York: Wiley, 3701-3709.

Kukulska-Hulme, A. and Shield, L. 2008. "An overview of mobile assisted language learning: From content delivery to supported collaboration and interaction". ReCALL, 20 (3), 271-289. doi:10.1017/S0958344008000335

Li, H. C. 2012. "Using podcasts for learning English: Perceptions of Hong Kong secondary 6 ESL students". ELT World Online, 4, 78-90.

Lynch, T. 2009. Teaching second language listening. Oxford: Oxford University Press.

Mayer, R. E. 2005. Cognitive theory of multimedia learning. In R. E. Mayer (Ed.), The Cambridge handbook of multimedia learning. New York: Cambridge University Press. 31-48. 
Mayer, R. E. 2009. Multimedia learning. New York: Cambridge University Press.

Mendelsohn, D. J. 1994. Learning to listen: A strategy-based approach for the second language learner. San Diego: Dominie Press.

Morell, T. 2004. La interacción en la clase magistral. Alicante: Servicio de Publicaciones de la Universidad de Alicante.

Morell, T. 2000. EFL content lectures: A discourse analysis of an interactive and a non-interactive Style. Alicante, Spain: Departamento de Filología Inglesa, Universidad de Alicante (Working papers, 7).

Norris, S. 2004. Analyzing multimodal interaction: A methodological framework. New York \& London: Routledge.

Norte, N. 2016. The orchestration of modes and EFL audio-visual comprehension: a multimodal discourse analysis of vodcasts. Department of English Studies, unpublished $\mathrm{PhD}$ thesis, Spain, University of Alicante.

O'Bryan, A. and Hegelheimer, V. 2007. "Integrating CALL into the classroom: The role of podcasting in an ESL listening strategies course”. Recall, 19(2), 162-180. doi:10.1017/S095834400700052

O’Halloran, K. L. and Smith, B. A. 2011. "Multimodal studies". In K. L. O’Halloran \& B. A. Smith (Eds.), Multimodal studies: Exploring issues and domains. New York: Routledge, pp. 1-13.

O’Malley, J. M. and Chamot, A. U. (Ed.) 1990. Learning strategies in second language acquisition. Cambridge: Cambridge University Press.

Prensky, M. (2001). "Digital Natives, Digital Immigrants Part I". On the Horizon, 9 (5), 1-6. doi.org/10.1108/10748120110424816

Ramírez, D. and Alonso, I. 2007. "Using digital stories to improve listening comprehension with Spanish young learners of English”. Language Learning \& Technology, 11(1), 87-101.

Rosell- Aguilar, F. 2007. "Top of the pods- in search of a podcasting "podagogy" for language learning". Computer Assisted Language, 20 (5), 471-492. doi:10.1080/09588220701746047 
Rost, M. 2002. Teaching and researching listening. Harlow, England: Longman.

Rubin, J. 1995. "The contribution of video to the development of listening comprehension”. In D.J. Mendelsohn \& J. Rubin (Eds.). A guide for the teaching of second language listening). San Diego: Dominie Press, Inc, 151-165.

Rubin, J. 1994. "A review of second language listening comprehension research". The Modern Language Journal, 78, 199-221. doi: 10.1111/j.15404781.1994.tb02034.x

Sinclair, J. and Coulthard, M. 1975. Towards an analysis of discourse: The English used by teachers and pupils. London: Oxford University Press.

Stockwell, G. and Hubbard, P. 2013. "Some emerging principles for mobile-assisted language learning”. Monterey, CA: The International Research Foundation for English Language Education. Retrieved from http://www.tirfonline.org/englishin-the-workforce/mobile-assisted-language-learning

Stracke, E. 2007. “A road to understanding: A qualitative study into why learners drop out of a blended language learning (BLL) environment". ReCALL 19 (1) 57-78.

Sueyoshi, A. and Hardison, D. 2005. "The role of gestures and facial cues in second language listening comprehension". Language Learning, 55, 661-699. doi:doi.org/10.1111/j.0023-8333.2005.00320.x

Suvorov, R. 2009. "Context visuals in L2 listening tests: The effects of photographs and video vs. audio-only format”. In C. A. Chapelle, H. G. Jun \& I. Katz (Eds.). Developing and evaluating language learning materials. Ames: Iowa State University, 53-68.

Vandergrift, L. 1997. "The Cinderella of communication strategies: Reception strategies in interactive listening". The Modern Language Journal, 81 (4), 494505. doi: 10.1111/j.1540-4781.1997.tb05517.x

Vandergrift, L. 2003. "Orchestrating strategy use: Towards a model of the skilled L2 listener". Language Learning, 53, 461-494. doi:10.3138/cmlr.59.3.425 
Vandergrift, L., Goh, C., Mareschal, C. and Tafaghodtari, M. H. 2006. "The metacognitive awareness listening questionnaire (MALQ): Development and validation". Language Learning, 56 (3), 431-462.

Ventola, E., Charles, C. and Kaltenbacher, M. (Eds.) 2004. Perspectives on multimodality. Amsterdam: John Benjamins.

Wagner, E. 2007. "Are they watching? An investigation of test-taker viewing behavior during an L2 video listening test”. Language Learning \& Technology, 11 (1), 6786. Retrieved from http://1t.msu.edu/vol11num1/wagner/

Wagner, E. 2010. "The effect of the use of video texts on ESL listening test-taker performance". Language Testing, 27, 493-513. doi:10.1177/0265532209355668 


\section{APPENDIX A: Questionnaire}

\section{QUESTIONNAIRE (FORMULARIO)}

\section{PART (PARTE) 1}

English Level (Nivel de inglés):

Age (Edad):

Sex (Sexo): female(mujer) male (hombre) Nationality(Nacionalidad):

- Years studying English (Años estudiando inglés):

\section{PART (PARTE) 2}

-Tick the correct number according to your opinion (Pon un tic en el número correcto según tu opinión).

1 - strongly disagree (totalmente en desacuerdo)

2 - disagree (en desacuerdo)

3 - neutral (neutral)

4 - agree (de acuerdo)

5 - strongly agree (totalmente de acuerdo)

\begin{tabular}{|l|l|l|l|l|l|}
\hline & $\mathbf{1}$ & $\mathbf{2}$ & $\mathbf{3}$ & $\mathbf{5}$ \\
\hline $\begin{array}{l}\text { 1. I found the video podcasts' sound quality better than in the usual } \\
\text { audio activities (La calidad de sónido del los "videos podcasts" me } \\
\text { pareció mejor que la de las actividades habituales de audio). }\end{array}$ & & & & & \\
\hline $\begin{array}{l}\text { 2. I found the video podcasts too long (Los "video podcasts" me } \\
\text { parecieron demasiado largos). }\end{array}$ & & & & & \\
\hline $\begin{array}{l}\text { 3. I found the speakers in the video podcasts talked slower than the } \\
\text { ones we listen to in normal audio exercises (Me pareció que los } \\
\text { hablantes de los "video podcasts" hablaban más lento que aquellos } \\
\text { que escuchamos en los ejercicios de audio). }\end{array}$ & & & & & \\
\hline $\begin{array}{l}\text { 4. I found the video podcasts more enjoyable and } \\
\text { entertaining than the listenings from the textbook (Los "video } \\
\text { podcasts" me parecieron más divertidos y entretenidos que los audios } \\
\text { del libro de texto). }\end{array}$ & & & & & \\
\hline \begin{tabular}{l} 
5. I found the video podcasts more difficult to understand than the \\
\hline
\end{tabular} & & & & & \\
\hline
\end{tabular}


listenings in class (Los "video podcasts" me parecieron más difíciles de entender que los audios de clase).

6. I felt less anxious watching the video podcasts and answering the exercises than in the usual listening activities (Me sentí menos nervioso viendo los "videos podcasts" y contestando a los ejercicios que con las actividades habituales de audio).

7. Do you prefer doing activities with video podcasts or the usual listening activities? Why?(¿Prefieres hacer actividades con "video podcasts" o las actividades frecuentes de audio?,¿ Por qué?).

8. Do you think that the use of video podcasts could help you to improve your level of English? Why? (¿Crees que el uso de "video podcasts” puede ayudarte a mejorar tu nivel de inglés?).

Received: 22 February 2016

Accepted: 4 April 2016

Cite this article as:

Norte Fernández-Pacheco, N. 2016. "Multimodal digital tools and EFL audio-visual comprehension: Students' attitudes towards vodcasts". Language Value 8 (1), 49-76. Jaume I University ePress: Castelló, Spain. http://www.e-revistes.uji.es/languagevalue. DOI: http://dx.doi.org/10.6035/LanguageV.2016.8.2

ISSN 1989-7103

Articles are copyrighted by their respective authors 